\title{
RELIGION AND VOTING BEHAVIOR Evidence from the 2017 Jakarta Gubernatorial Election
}

\author{
Saiful Mujani \\ Syarif Hidayatullah State Islamic University (UIN), Jakarta \\ email:saiful.mujani@uinjkt.ac.id
}

\section{Abstract}

In voting behavior studies, the effect of religion on partisan choice relative to psychological factors and political economy has not been conclusively determined. In Indonesian politics, religion has frequently been understood as a typology of Muslim religiosity, i.e. santri versus abangan, or orthodox versus heterodox Muslim. This conception does not significantly predict election outcomes. The effect of religious identity, i.e. Islam versus other religion, on voting is not discernable so far because it has not been systematically tested. The 2017 Jakarta gubernatorial election is a rare instance in which the contestants have different religious identities in an almost homogenous society. This setting is ideal. This essay reports the results of a test from public opinion surveys prior to and an exit poll on election day. The result verified that religion explains very significantly how the Muslim candidate won. Political economy and partisanship, however, save the incumbent from a big loss. These findings have more systematically revised the existing comparative and Indonesian literature on the relationship between religion and voting behavior.

[Dalam studi perilaku memilih, perbandingan pengaruh agama, faktor psikologis, maupun ekonomi politik, terbadap pilihan partai atau calon dalam pemiliban umum belum konklusif. Dalam politik. Indonesia, agama sering difahami dalam tipologi keberagamaan santri versus abangan, atau Muslim puritan versus Muslim sinkretis. Konsepsi agama ini tidak punya pengaruh signifikan terhadap perilaku memilih dalam pemiliban umum sejauh ini. Sementara itu pengarub identitas agama, yakni Islam versus agama lainnya, 
terbadap perilaku memilih sejauh ini juga tidak banyak terlihat karena belum teruji secara sistematik. Pemiliban gubernur DKI Jakarta 2017 adalah contoh kasus langka di Indonesia di mana calon-calon gubernurnya punya identitas agama berbeda sementara pemilibnya hampir homogen dilibat dari identitas agamanya. Keadaan ini ideal untuk. menguji pengaruh identitas agama terhadap perilaku memilib. Artikel ini merupakan laporan basil uji perbandingan pengarub identitas agama, faktorpsikologis, dan ekonomi-politik. pada perilaku memilih gubernur, dan bersandarpada data survei opinipublik. sebelum dan di haripemiliban. Hasilnya membuktikan babwa identitas agama sangat mempengarubi bagimana calon gubernur beragama Islam menang dalam pemiliban tersebut. Namun demikian, pengarub ekonomi-politik dan identitas kepartaian menolong petahana yang non-Muslim dari kekalahan telak. Temuan-temuan ini merevisi referensi studi politik perbandingan dan Indonesia terkait hubungan agama dan perilaku memilib.]

Keywords: voting behavior, religion, political economy, personal qualities, partisanship, Jakarta gubernatorial election

\section{A. Introduction}

The world watched closely the Jakarta gubernatorial election held in February and April 2017. The election attracted huge attention because Basuki Tjahaja Purnama, popularly called Ahok, the incumbent, had been charged several months earlier with violating the controversial blasphemy law. ${ }^{1}$ His trial dismayed his campaign managers; in their eyes,

1 Ahok was alleged to have violated blasphemy laws when he stated that Muslims have been deceived by those who use Qur'anic verse al-Maidah 51 to claim that Muslims should not vote for him. The verse states that Muslims are not allowed to be led by non-Muslims. The judge found that Ahok's wording, "using the al-Maidah verse 51 of the Qur'an to deceive Muslims" meant that he had insulted the verse, or that he had viewed the verse as the source of a lie, and therefore he had insulted the verse. See Dian Andryanto, "Ahok Dihukum Dua Tahun, Putusan Hakim Bulat", Tempo (9 May 2017), https://nasional.tempo.co/read/873676/ahok-dihukum-duatahun-putusan-hakim-bulat, accessed 30 Jul 2020; Rina Atriana Mardiastuti Aditya, "Hakim: Ahok Merendahkan Surat Al-Maidah 51", detiknews (9 May 2017), https:// news.detik.com/berita/d-3496149/hakim-ahok-merendahkan-surat-al-maidah-51, accessed 30 Jul 2020; Dwiarso Budi Santiarto, "Ini Kisah Perjalanan Kasus Ahok Hingga Vonis 2 Tahun Penjara”, Tribunnews.com (16 Nov 2016), https:/ /www.tribunnews. com/metropolitan/2017/05/09/ini-kisah-perjalanan-kasus-ahok-hingga-vonis-2- 
it was obviously part of a negative campaign. Ahok's opponents claimed that he was put on trial because he had insulted Islam, the faith of $85 \%$ of Jakartans. Ahok is Christian. His supporters believed the charge was unjust. It reflected only Ahok's opinion, for which he could not be tried. Blasphemy laws themselves are believed to violate human rights and the Indonesian Constitution itself as Indonesia has amended its constitution to accommodate universal human rights and norms including an article which states that "Each person has the right to be free in his convictions, to assert his thoughts and tenets, in accordance with his conscience". ${ }^{2}$ However, a challenge to Blaspehmey law, which is believed inimical to the Constitution, through a constitutional review in the constitutional court, has been rejected by the court, and therefore the law still survives. ${ }^{3}$

The laws on which the court finds Ahok guilty and sent him to prison are the blasphemy law articles 1-3, and Criminal Codes (Kitab Undang-Undang Hukum Pidana or KUHP) article 156A. ${ }^{4}$ Blasphemy Law article 1 states: "Every person is prohibited from intentionally, in public, telling, advocating or contriving public support for carrying out interpretations of religion adhered to in Indonesia or conducting religious activities that resemble religious activities of that religion, interpretations, and activities that deviate from the fundamental teachings of that religion." ${ }^{5}$ In addition, the court found Ahok guilty according to the KUHP article 154A which states that: "Punishable by up to five years' imprisonment whoever, intentionally, in public, expresses a feeling or conducts themselves in a way that: $\mathrm{a}$ is principal of a nature of enmity

tahun-penjara?page=3, accessed 30 Jul 2020; "Jakarta Election: Christian Governor Concedes to Muslim Rival”, BBC News (19 Apr 2017), https://www.bbc.com/news/ world-asia-39636974, accessed 30 Jul 2020; Kate Lamb, "Jakarta Governor likely to be spared jail if found guilty of insulting Islam”, the Guardian (20 Apr 2017), http:// www.theguardian.com/world/2017/apr/20/ousted-jakarta-governor-basuki-tjahajapurnama-jail-blasphemy-indonesia, accessed 30 Jul 2020.

2 See The Constitution of the Republic of Indonesia of 1945, chap. X A, article 28 E: 2, http://www.unesco.org/education/edurights/media/docs/ b1ba8608010ce0c48966911957392ea8cda405d8.pdf.

3 See Daniel Peterson, Islam, Blasphemy, and Human Rights in Indonesia: The Trial of Ahok, 1st edition (London: Routledge, 2020).

4 Ibid., p. 5.

5 Ibid. 
toward, abusive, or sullying of a religion followed in Indonesia; intends to discourage persons from embracing a religion based on the belief in Almighty God; b intended to stop a person from adhering to any religion based on Almighty God." ${ }^{6}$ Regardless of the court's controversial decision, Ahok was sent to jail.

Ahok's run for the governorship via a direct election is a special and rare case in Indonesian democracy, and probably worldwide, as he is from a religio-ethnic minority. Elections usually involve contestants from the same social identities. ${ }^{7} \mathrm{He}$ is Sino-Christian, a minority group in the majority Malay-Muslim community in Jakarta and Indonesia. Christians (Protestant and Catholic) are about 8\% nationally, and about 11\% in Jakarta. ${ }^{8}$ Sino-Indonesians are about $2 \%$ nationally and $7 \%$ in the city. Many Muslims believe that a strategic position such as governor should be held by a fellow believer. Specifically, a minority Christian should not rule a majority Muslim community. ${ }^{\text {? }}$

From an inclusive political perspective, on the other hand, if a Muslim vote for a non-Muslim gubernatorial candidate, he or she will be viewed as pluralist and tolerant. A citizen from any religio-ethnic group is equal in political rights and is entitled to participate in public life, including contestation for office. This perspective fits the expectations of most Indonesian leaders. They believe Indonesian Muslims are more open and tolerant than Muslims in most other Muslim countries. Indonesian Islam

\section{Ibid.}

7 Ahok was vice-governor and became governor when Governor Joko Widodo stepped down to run for president.

8 These proportions are based on the national census in 2010. Penduduk Indonesia: Hasil Sensus Penduduk 2010 (Jakarta: BPS - Statistic Indonesia, 2012).

9 Peterson, Islam, Blasphemy, and Human Rights in Indonesia; Syafiq Hasyim, "MUI and its discursive relevance for 'Aksi Bela Islam': A Growing Trend of Islamic Conservatism in Indonesia", in Rising Islamic Conservatism inIndonesia, ed. by Leonard C. Sebastian, Syafiq Hasyim, and Alexander R. Arifianto (Routledge, 2020), pp. 116-32. 
thus deserves its reputation. ${ }^{10}$ This pluralism is required for democracy. ${ }^{11}$

The results of the Jakarta gubernatorial elections in 2007 and 2012 reflected that hope. ${ }^{12}$ All the candidates for governor were Muslim. The relevance of this for Indonesian electoral studies is the continuing reliance by scholars and other observers on Clifford Geertz's ${ }^{13}$ classic analysis of Indonesian Islam. Geertz was concerned with types of Muslim religiosity, not religious identity. He divided Muslims into two types: pious or orthodox (santri) and syncretic or heterodox (abangan). He did not study Islam versus other religions. Geertz claimed that these two types of Muslims shaped politics in Indonesia. His analysis has been supported by many other scholars. ${ }^{14}$

In democratic Indonesia, Geertz's typology is still relevant, at least as reflected in party ideologies. In 2007, Fauzi Bowo, who was supported by the large secular parties like PDI-Perjuangan (Indonesian Democracy Party of Struggle) and Partai Golkar (Functional Groups Party), defeated Adang Daradjatun who was supported by the religious parties. In that election, Fauzi (whose running mate was a retired marine officer) won $58 \%$ of the vote, while Adang, a retired police general whose running mate was an Islamist PKS (Prosperous Justice Party) cadre, won $42 \%$.

${ }^{10}$ Jeremy Menchik and Katrina Trost, “A ‘Tolerant' Indonesia? Indonesian Muslims in Comparative Perspective", in Routledge Handbook of Contemporary Indonesia (London: Routledge, 2018), pp. 390-405; Thomas Harming Suwarta, "Indonesia Menjadi Kiblat Toleransi di Dunia”, Media Indonesia (2 Jul 2017), https:/ / mediaindonesia. $\mathrm{com} /$ politik-dan-hukum/111128/indonesia-menjadi-kiblat-toleransi-di-dunia, accessed 29 Jul 2020; “Indonesia Should Become Reference for Studying Moderate Islam”, News en.tempo.co, https://en.tempo.co/read/1277030/indonesia-should-become-referencefor-studying-moderate-islam-vp, accessed 29 Jul 2020.

11 Robert Dahl, The Future of Democratic Theory, Estudios / Working Papers, no. 90 (La Rioja: Centro de Estudios Avanzados en Ciencias Sociales, 1996).

12 Ken Miichi, "The Role of Religion and Ethnicity in Jakarta's 2012 Gubernatorial Election”, Journal of Current Southeast Asian Affairs, vol. 33, no. 1 (2014), pp. 55-83.

13 Clifford Geertz, The Religion of Java (Glencoe, Illinois: Free Press, 1960).

14 Afan Gaffar, Javanese Voters: A Case Study of Election Under a Hegemonic Party System (Yogyakarta: Gadjah Mada University Press, 1992); Anthony King (ed.), Leaders' Personalities And The Outcomes Of Democratic Elections, 1st edition (Oxford: Oxford University Press, 2002). 
Fauzi's vote in this election is reminiscent of Anies's in $2017 .{ }^{15}$

In 2012, the incumbent Fauzi Bowo was defeated 54\% to 46\% by Joko Widodo (familiarly called Jokowi). Jokowi was supported by PDI-Perjuangan and Gerindra (Greater Indonesia Movement). These two parties are known to be secular, or at least have definitively not been labeled Islamic parties or ones that have a historic connection with Islamic politics. But Fauzi deployed much religious sentiment in his campaign, which one study called "religionalization." It is stated that "The incumbent governor, Fauzi Bowo, carefully established his religious image and tried to mobilize support through religious symbols and persuasion, even though the electoral results seemed to be divided along ethnic lines". ${ }^{16}$ Jokowi comes from Solo, a Central Java city that may be called the heart of heterodox as opposed to orthodox Islam. Jokowi himself is heterodox, supported by the secular PDI Perjuangan and Gerindra. His running mate was Ahok, a Sino-Indonesian Christian. Their victory appeared to fulfill the hope that Muslims in Jakarta were rational voters, because most did not choose a candidate identified with Islam or Islamic-based political parties. Indonesia is one of very few democracies in the Muslim world. Jokowi and Ahok's victory in the gubernatorial election, and Jokowi's subsequent election as president, seemed to be strong evidence of the existence of rational Muslim democrats. ${ }^{17}$

The 2017 gubernatorial election reversed that perception and hope. Putting Governor Ahok on trial during a campaign because of his opinion is both contrary to what he actually said and to the hopes of many as to what would happen to him as a result. The Ahok affair has disappointed pluralist Muslims and their sympathizers, reducing the hope that Muslims can build a modern polity and that Indonesia may become a model for

15 Heru Purwanto, "KPU Tetapkan Fauzi Bowo-Prianto Pemenang Pilkada DKI 2007”, Antara News (16 Aug 2007), https:/ /www.antaranews.com/berita/74054/ kpu-tetapkan-fauzi-bowo-prianto-pemenang-pilkada-dki-2007, accessed 29 Jul 2020.

16 Miichi, "The Role of Religion and Ethnicity in Jakarta's 2012 Gubernatorial Election", p. 1.

17 Saiful Mujani, Muslim Demokrat: Islam, Budaya Demokrasi dan Partisipasi Politik di Indonesia Pasca Orde Baru (Jakarta: Penerbit Gramedia Pustaka Utama - Pusat Pengkajian Islam dan Masyarakat, Yayasan Wakaf Paramadina, Freedom Institute, and Kedutaan Besar Denmark, 2007). 
Muslim democracy. ${ }^{18}$ This is consistent with scholarly assessments in the last 5 years that Indonesian democracy has regressed. ${ }^{19}$

In addition, many judged Ahok's performance as governor successful. ${ }^{20}$ Pluralist Muslims therefore supported him regardless of his social identity. Pressure and campaigns against his reelection because of his identity reduced the hope that Muslims can be rational in their political behavior and that a positively performing incumbent deserves to be reelected. ${ }^{21}$ The failure of Ahok to be elected governor in his own right is actually not surprising. He was elected vice-governor in 2012 as Jokowi's running mate. They won that election, but it was not a clear test since Jokowi, a Javanese Muslim, was at the head of the ticket and Ahok, a Sino-Christian, was subordinate to him. There was no significant religion-based reaction against them during the campaign. In 2014, Jokowi stepped down to run for president. According to law, the vice-governor automatically becomes governor if the elected governor steps down. Ahok was, therefore, never directly elected governor. If he had run for governor in 2012 he probably would not have won.

However, prior to his runs for vice-governor in 2012 and governor

18 Joe Cochrane, "Jakarta Governor Concedes Defeat in Religiously Tinged Election”, The New York Times (19 Apr 2017), https:/ /www.nytimes.com/2017/04/19/ world/asia/jakarta-election-ahok-anies-baswedan-indonesia.html, accessed 30 Jul 2020.

19 Marcus Mietzner, "Rival Populisms and the Democratic Crisis in Indonesia: Chauvinists, Islamists and Technocrats", Australian Journal of International Affairs, vol. 74, no. 4 (Routledge, 2020), pp. 420-38; Marcus Mietzner, "Fighting Illiberalism with Illiberalism: Islamist Populism and Democratic Deconsolidation in Indonesia", Pacific Affairs, vol. 91, no. 2 (2018), pp. 261-82; Marcus Mietzner and Burhanuddin Muhtadi, "Explaining the 2016 Islamist Mobilisation in Indonesia: Religious Intolerance, Militant Groups and the Politics of Accommodation", Asian Studies Review, vol. 42, no. 3 (2018), pp. 479-97; Edward Aspinall and Marcus Mietzner, "Indonesia’s Democratic Paradox: Competitive Elections amidst Rising Illiberalism", Bulletin of Indonesian Economic Studies, vol. 55, no. 3 (2019), pp. 295-317; Jeremy Menchik, "Moderate Muslims and Democratic Breakdown in Indonesia”, Asian Studies Review, vol. 43, no. 3 (2019), pp. 415-33.

20 Popular assessment of Ahok's performance as governor will be presented in the findings.

${ }^{21}$ Roderick Kiewiet, Macroeconomics and Micropolitics: The Electoral Effects of Economic Issues (Chicago, Ill.: Univ of Chicago Pr, 1984); Michael S. Lewis-Beck, Economics and Elections: The Major Western Democracies (Ann Arbor: University of Michigan Press, 1990); Saiful Mujani, R. William Liddle, and Kuskridho Ambardi, Voting Bebavior in Indonesia since Democratization: Critical Democrats (Cambridge: Cambridge University Press, 2018). 
in 2017, Ahok had been elected district head in his home town of East Belitung a municipality in Bangka Belitung, Sumatra. Muslims are a majority, but there are many Sino-Indonesians. ${ }^{22}$ In addition, he was elected from Partai Golkar (Golkar Party) to the national parliament from Bangka Belitung. In Indonesia's election system, a variant of the open proportional system, a candidate can win a seat without winning a majority of the votes. In addition, for district head elections, a candidate can win by a plurality with $30 \%$. In the case of Jakarta, however, an absolute majority is necessary. In the first round, Ahok won the largest vote $(43 \%)$ but it was not enough.

Religion is actually not consistently significant in Indonesian electoral politics because minority contestants are not very common. ${ }^{23} \mathrm{It}$ has never occurred in a presidential and rarely in gubernatorial elections. ${ }^{24}$ Identity politics looks strong not only among Muslims but also adherents of other religions. A Muslim has never become governor in a majority non-Muslim region such as Bali (Hindu), Nusa Tenggara Timur, Sulawesi Utara, Papua and Papua Barat (all Christian). Minority victories have occurred in some legislative elections.

Ahok's run for governor is thus an important test. Students of politics who are concerned with this issue should learn from this case, especially since this is the first systematic analysis. The applicability of three competing models can be tested: Identity politics versus psychological versus rational choice models. ${ }^{25}$ How significant is social identity, i.e. religion and ethnicity, relative to party identification and

${ }^{22}$ According to the Central Bureau of Statistics, Muslims are $80 \%$, SinoIndonesians 15\%. See Penduduk Indonesia: Hasil Sensus Penduduk 2010 Jakarta: BPS - Statistic Indonesia, 2012).

23 Mujani, Liddle, and Ambardi, Voting Behavior in Indonesia since Democratization.

24 Cornelis, a Catholic, won twice in the Muslim majority province of West Kalimantan, serving from 2008-2018, mainly due to the failure of Muslim politicans to nominate a single candidate. In the most recent election in 2018, Muslim politicians selected a single candidate against another Catholic, Cornelis's daughter, and won. A similar case occured in Central Kalimantan, also a Muslim majority province, where a Catholic was elected governor in the absence of a single Muslim candidate. In the last election they resolved this problem and the Catholic candidate was defeated.

25 Richard G. Niemi and Herbert F. Weisberg (eds.), Classics in Voting Behavior (Washington, D.C: CQ Press, 1992); Warren E. Miller and J. Merrill Shanks, The New American Voter (Cambridge, Mass: Harvard University Press, 1996). 
political economy in the Jakarta election? The result should empirically refine previous findings in a currently inconclusive literature. Some national-level studies of Indonesia have found that party identification, personal qualities, and political economy are more significant in voting for president and legislators than religion and ethnicity. ${ }^{26}$ However, what these studies tested is Geertz's ${ }^{27}$ division of Indonesian Muslims into orthodox and heterodox types, as described above.

Geertz was not concerned with religion as belonging or identity ${ }^{28}$ as almost everybody in the country is Muslim. Especially at the national level, political contestation has been relatively free from religious identity. The contestants vary only in terms of their Islamicness or Islamic religiosity, or orthodox versus heterodox as introduced by Geertz. More recent studies suggest that religion as identity is likely to be significant in electoral politics if the contestants vary in those terms, e.g., Muslim versus Christian. ${ }^{29}$ Our first of its kind systematic study will hopefully contribute both to the comparative literature and to Indonesian electoral studies.

\section{B. Hypotheses}

There are three potential explanations of voting behavior relevant to the Jakarta election. They will likely help explain Ahok's failure which at the time sparked debates among journalists, politicians, public intellectuals, and scholars. The first is the religio-ethnic identity explanation; the second the psychological, including personal qualities and partisanship or party ID; the third is rational choice, mainly concerned with the voter's assessment of economic condition and incumbent performance.

Our conceptualization of identity politics in voting behavior is simple. A citizen is likely to vote for a candidate because he or she and

26 Mujani, Liddle, and Ambardi, Voting Behavior in Indonesia since Democratization; R. William Liddle and Saiful Mujani, "Leadership, Party, and Religion: Explaining Voting Behavior in Indonesia", Comparative Political Studies, vol. 40, no. 7 (2007), pp. 832-57.

27 Clifford Geertz, The Religion of Java (Glencoe, Illinois: Free Press, 1960).

28 David C. Leege and Lyman A. Kellstedt, Rediscovering the Religious Factor in American Politics (Armonk, N.Y: Routledge, 1993).

29 Mujani, Liddle, and Ambardi, Voting Behavior in Indonesia since Democratization. 
the candidate share a religio-ethnic identity. ${ }^{30} \mathrm{~A}$ voter is not likely to vote for a candidate whose religio-ethnic background is different. A Muslim relative to a Christian or non-Muslim, a non-Sino-Indonesian relative to Sino-Indonesians is unlikely to vote for Ahok. Why does identity matter? Two broad perspectives offer answers: cultural and rational, or substantive and instrumental. ${ }^{31}$ The cultural perspective refers to group membership in which identification is mainly based on ascriptive values and how this affects behavior. ${ }^{32}$ Close to this view, "social identity refers to bonds of belonging in which a person within the bond feels satisfied with the bonding". ${ }^{33}$ This feeling produces affection toward the identified group and is the core of social identity.

The rational or instrumental perspective assumes that social identity is epiphenomenal to material interests. Social identity here refers more to its usefulness to achieve material self-interest rather than to ascriptive values. It helps reduce uncertainty about the world. ${ }^{34}$ Religio-ethnic identity mobilization is likely to be more effective in a society deeply divided by class. In Jakarta and Indonesia, a Sino-Christian minority has dominated the city and national economies. Of the 15 richest men, 13 are Sino-Indonesian, 1 Malay, and 1 Indian. ${ }^{35}$ It would not be surprising if some believe that Ahok represents rich Sino-Indonesians. The Islamist opposition party PKS claimed that Ahok's policies were pro-capitalist. ${ }^{36}$

30 Arend Lijphart, "Religious vs. Linguistic vs. Class Voting: The 'Crucial Experiment' of Comparing Belgium, Canada, South Africa, and Switzerland”, The American Political Science Review, vol. 73, no. 2 (1979), pp. 442-58.

31 Michael Kalin and Nicholas Sambanis, "How to Think About Social Identity", Annual Review of Political Science, vol. 21, no. 1 (2018), pp. 239-57.

32 Kanchan Chandra, "What Is Ethnic Identity and Does It Matter?", Annual Review of Political Science, vol. 9, no. 1 (2006), pp. 397-424.

33 Donald L. Horowitz, Ethnic Groups in Conflict, Updated Edition With a New Preface, 2nd edition (Berkeley, Calif.: University of California Press, 2000).

${ }^{34}$ Henry E. Hale, "Explaining Ethnicity", Comparative Political Studies, vol. 37, no. 4 (2004), pp. 458-85.

35 Mutia Fauzia, "Ini 15 Orang Terkaya di Indonesia Tahun 2020 Halaman all”, KOMPAS.com (9 Apr 2020), https:/ / money.kompas.com/read/2020/04/09/124003226/ ini-15-orang-terkaya-di-indonesia-tahun-2020, accessed 30 Jul 2020.

36 Dyah Ratna Meta Novia, "PKS Sebut Kebijakan Ahok Berpihak pada Kelompok Pemilik Modal", Republika Online (17 Apr 2016), https://republika.co.id/ berita/nasional/jabodetabek-nasional/16/04/17/o5r3iu336-pks-sebut-kebijakan-ahok- 
The social class gap is likely to help make religio-ethnic identity mobilization more effective. This sentiment was not very intense in Ahok's previous experience in Bangka Belitung and in many similar cases. Ahok's family was known to care about and be engaged with ordinary people. Ahok's selection as a legislator can partially be explained by the fact that in legislative elections there are many contestants, blurring religioethnic and social class identities. Social identity may have a rational effect. Identity as a non-material norm may effect political behavior as it meets material interest. "Identity matters because of a mixture of material and nonmaterial motivations, and rational explanations need not ignore one or the other type of motivation". ${ }^{37}$ This study expects that religio-ethnic identity effects on voting for governor will decrease as the social class becomes more prominent.

The rational choice perspective suggests that protest against incumbents is likely as a result of dissatisfaction with the economy. Voters will vote for the incumbent if the economic condition under his or her leadership is good. ${ }^{38} \mathrm{~A}$ voter who believes Jakarta's current economic condition is better than last year will vote for Ahok. Political parties are also expected to repress religio-ethnic sentiments. Religio-ethnic identity as a factor will decrease significantly when party identification is more important to the voter. ${ }^{39}$

Another hypothesis is that a candidate's personal qualities matter. ${ }^{40}$

berpihak-pada-kelompok-pemilik-modal, accessed 30 Jul 2020.

37 Kalin and Sambanis, "How to Think About Social Identity", p. 257.

38 Saiful Mujani, R. William Liddle, and Kuskridho Ambardi, Voting Behavior in Indonesia since Democratization: Critical Democrats (Cambridge: Cambridge University Press, 2018); Wouter van der Brug, Cees van der EijK, and Mark Franklin, The Economy and the Vote: Economic Conditions and Elections in Fifteen Countries, 1st edition (Cambridge University Press, 2007); Michael S. Lewis-Beck, Economics and Elections: The Major Western Democracies (Ann Arbor: University of Michigan Press, 1990); Roderick Kiewiet, Macroeconomics and Micropolitics: The Electoral Effects of Economic Issues (Chicago, Ill.: Univ of Chicago Pr, 1984); Morris P. Fiorina, Retrospective Voting in American National Elections (Yale: Yale University Press, 1981).1990

39 R. William Liddle, Ethnicity, Party, and National Integration;: An Indonesian Case Study (New Haven: Yale University Press, 1970).

40 Mujani, Liddle, and Ambardi, Voting Behavior in Indonesia since Democratization; King (ed.), Leaders' Personalities And The Outcomes Of Democratic Elections; Clive Bean and Anthony Mughan, "Leadership Effects in Parliamentary Elections in Australia and 
Many observers and politicians claimed that Ahok's personal qualities as a leader were a negative factor. ${ }^{41}$ The personality issue refers to his volatile temper, including impulsive, arrogant, and impolite speech. Ahok's defeat was expected mainly due to that bad temper. He was alleged to be an unlikeable candidate.

\section{Measures}

The dependent variable is voting for Ahok relative to Anies. ${ }^{42}$ The independent variables are religious affiliation or religious belonging, religio-political sentiments, ethnic background, ethnicity-based political sentiment, personal qualities, party support as a proximate measure of party identification or partisanship, incumbent performance, economic condition, education, income, age, and gender (Appendix 1 for all measures and wordings). ${ }^{43}$ Education and income are measures of social class at the individual level. In this study, social identity is not only defined in terms of belonging to a particular religion or ethnicity but also in terms of the intensity of religio-political and ethno-political sentiment. The two measures are expected to be more sensitive in discerning

Britain”, The American Political Science Review, vol. 83, no. 4 (1989), pp. 1165-79; Brian Graetz and Ian Mcallister, "Party Leaders and Election Outcomes in Britain, 1974-1983"' Comparative Political Studies, vol. 19, no. 4 (1987), pp. 484-507.

41 "PKS: Ahok Harus Tegas, tetapi Jangan Kasar", KOMPAS.com (20 Jul 2015), https://money.kompas.com/read/2015/07/20/15215531/PKS.Ahok.Harus.Tegas. tetapi.Jangan.Kasar, accessed 30 Jul 2020; Humas PKS Jakarta, "Surat Terbuka Wasekjen PKS ke Ahok Soal Kata-kata Kasar di Televisi”, DPTW PKS DKI JAKARTA (20 Mar 2015), http://pks-jakarta.or.id/surat-terbuka-wasekjen-pks-ke-ahok-soal-kata-katakasar-di-televisi/, accessed 31 Jul 2020.

42 In the surveys, as in the election, respondents were asked to vote for a pair of candidates, Basuki Tjahaja Purnama - Saiful Hidayat or Anies Baswedan-Sandiaga Uno. In this essay, the pair is simplified as Ahok or Anies.

43 Party identification is consistently very low in Indonesia as measured by self identification with a party or by the intensity of identification as suggested by the standard measure of party identification.See Samuel H. Barnes et al., "Party Identification and Party Closeness in Comparative Perspective", Political Behavior, vol. 10, no. 3 (1988), pp. 215-31; Angus Campbell et al., The American Voter (Chicago Ill.: University of Chicago Press, 1980). The proportion is only about $10 \%$. The variation is low. See Mujani, Liddle, and Ambardi, Voting Behavior in Indonesia since Democratization. Party vote if the election for legislators is held today is an alternative measure of party identification. The result varies very significantly, as is shown in this study. 
political identity (Appendix 1). Religion-based mobilization against Ahok was at its peak massive. Hundreds of thousands demonstrated in front of the presidential palace to demand that Ahok be sent to jail for blaspheming Islam. ${ }^{44}$ Prior to the demonstration, national Police Chief Tito Karnarvian stated that Ahok could not be charged because he did not intend to blaspheme. ${ }^{45}$ Immediately after, Ahok became a potential suspect, demonstrating how public opinion is capable of shaping voting behavior as well as real-world events. Substantively, the Ahok prosecution was related to a Qur'anic verse, al-Maidah 51, which states that Muslims are not allowed to be led by Christians or Jews. Muslims are expected not to vote for Ahok.

\section{Method, Data, and Findings}

To verify the hypotheses a series of public opinion surveys were conducted prior to the election and an exit poll was conducted on election day. The population is all Jakarta voting-age citizens. A significant number of members of the population were selected at random. See Appendix 2.

Ahok was defeated by a margin of 15,9 percent. ${ }^{46}$ Prior to election day, a series of public opinion surveys indicated that Ahok had never been ahead, though the margins fluctuated..$^{47}$ Voting behavior had indeed been relatively stable regardless of campaigns and mass mobilization. In surveys as far back as two years, Ahok had never won an absolute majority, even before there was a definitive challenger. ${ }^{48}$

How to explain the failure of Ahok or the victory of Anies? Sociological, political economy or rational choice, and psychological factors can help provide an answer. To begin, the following descriptive

44 Hasyim, "MUI and its discursive relevance for 'Aksi Bela Islam': A Growing Trend of Islamic Conservatism in Indonesia".

45 "Kapolri: Bukan Membela, Ahok Tidak Bermaksud Menistakan Agama", liputan6.com (5 Nov 2016), https://wwwliputan6.com/news/read/2644597/kapolribukan-membela-ahok-tidak-bermaksud-menistakan-agama, accessed 31 Jul 2020.

46 "Pilkada Provinsi DKI Jakarta (Putaran Kedua)", KPU-Portal Publikasi Pemilihan Kepala Daerah 2017, https://pilkada2017.kpu.go.id/hasil/2/t1/dki_jakarta, accessed 30 Jul 2020.

47 Saiful Mujani, Agama dan Rasionalitas Pemilib: Kasus Pemiliban Gubernur DKI Jakarta 2017 (Jakarta: Saiful Mujani Research and Consulting, 2017).

48 In August 2015 only 23,5\% voted for Ahok. Ibid. 
statistics provide information about the characteristics of Jakarta voters (Table 1).

Table 1. Descriptive Statistics (Pooled Data)

\begin{tabular}{lrrrrr}
\hline \multicolumn{1}{c}{ Voter Characteristics } & N & Minimum & Maximum & Mean & $\begin{array}{r}\text { Standard } \\
\text { Deviation }\end{array}$ \\
\hline Voting for Purnama- & & & & & \\
Hidayat & 4751 & .00 & 1.00 & .4204 & .49368 \\
Purnama insulted Islam & 4751 & 1.00 & 3.00 & 2.2072 & .84194 \\
Muslim leader & 4751 & 1.00 & 5.00 & 3.3183 & 1.29934 \\
Ethnic majority leader & 4751 & 1.00 & 5.00 & 2.7475 & 1.14583 \\
Incumbent performance & 4751 & 1.00 & 5.00 & 3.6176 & 1.18816 \\
Economic condition & 4751 & 1.00 & 5.00 & 3.3640 & .95037 \\
Likability of Purnama & 4751 & 1.00 & 3.00 & 2.2905 & .94022 \\
Partisanship & 4751 & 1.00 & 3.00 & 2.0910 & .83818 \\
Education & 4745 & 1.00 & 10.00 & 6.5316 & 2.31008 \\
Income & 4632 & 1.00 & 17.00 & 9.3340 & 3.85822 \\
Religion: Islam & 4751 & .00 & 1.00 & .8540 & .35314 \\
Ethnicity: Javanese & 4751 & .00 & 1.00 & .3620 & .48063 \\
Age & 4751 & 17.00 & 89.00 & 40.3865 & 14.29776 \\
Gender: Male & 4751 & .00 & 1.00 & .5070 & .50000 \\
\hline
\end{tabular}

According to the most recent census, the proportions of male and female are about equal. Average age is 40 . Income and education levels (high school graduates) are modest. Muslims account for 85,4\% of the voting population. ${ }^{49}$ The voters are ethnically diverse, with Javanese the largest group at about 36\%. Native Jakartans (Betawi) is the second, followed by Sundanese, the majority group in the neighboring province of West Java. Crucially, Sino-Indonesians are only 6,6\%. Ahok was seriously constrained by these demographic facts. Among Muslim voters, a majority believed that a non-Muslim should not lead Muslims (Table 1). On a 5 point scale, the mean was 3,32 meaning that most Muslims prior to and on election day rejected non-Muslims' leadership. Moreover, Ahok was

49 The rest are Protestants (7,5\%), Catholics (3,2\%), Buddhists (3,3\%), Hindus $(0,2 \%)$, Confucians $(0,1 \%)$, and other $(0,4 \%)$. BPS Provinsi DKI Jakarta, Hasil Sensus Penduduk 2010 Data Agregatper Kabupaten Kota Provinsi DKI Jakarta (Jakarta: BPS Provinsi DKI Jakarta, 2010); "Penduduk Menurut Wilayah dan Agama yang Dianut: Provinsi DKI Jakarta”, BPS-Sensus Penduduk 2010, http://sp2010.bps.go.id/index.php/site/tabe l?wid=3100000000\&tid=321\&fi1 =58\&fi2 =3, accessed 31 Jul 2020; Penduduk. Indonesia: Hasil Sensus Penduduk 2010, p. 202. 
in jail, convicted of blasphemy. ${ }^{50} \mathrm{~A}$ majority of voters who agreed with the conviction accepted the prosecution's claim. On a 3 point scale, the mean was 2,22 meaning that most agreed the prosecution was just. This attitude was consistently high prior to and on election day. ${ }^{51}$

The potential for ethno-political sentiment to discriminate against the Sino-Christian Ahok was lower. Some members of ethnic majorities believe that they should not be led by a member of a minority. On this measure, a majority disagree or are at least neutral (Table 1). As an Arab-Indonesian, Anies also belongs to a minority, which makes ethnic sentiment less significant.

In comparison to the negative impact of religio-identity, assessments of economic condition, the incumbent governor's performance, and opinion about Ahok's personal qualities were in general positive. Most stated that the economic condition during the election year had been better than the previous year. On a 5 point scale the mean was 3,36 (Table 1), which should have increased the incumbent's vote. On incumbent performance, or job approval, most voters were satisfied. On a 5 point scale, the mean was 3,62, meaning satisfied, which should increase the incumbent's vote. In addition, Ahok was likable, despite the widespread critique. His likability score was 2,29 on a 3 point scale, which should have increased his vote. The multivariate analysis demonstrates the relative effect of each independent variable on the dependent variable, i.e. voting for a candidate ${ }^{52}$ (Table 2). The effect varies as follows.

50 According to law, one can be charged as a criminal if his or her opinion or behavior can be proved to publicly insult a religion. See Mudzakkir, Tindak Pidana Terbadap Agama Dalam Kitab Undang Undang Pidana (KUHP) dan Undang Undang Nomor $1 /$ PNPS/ 1995 Tentang Pencegahan Penyalahgunaan dan/atau Penodaan Agama: (Kajian Terbadap Praktek Penegakan Hukum dan Prospek. Pengaturannya Dalam Hukum Positif Indonesia), (Jakarta: Kementerian Hukum dan Hak Asasi Manusia, 2010).

51 Mujani, Muslim demokrat.

52 This multivariate analysis is based on logistic regression, an appropriate statistical model for a categorical dependent variable such as voting for governor, i.e. voting for Ahok (coded 1) relative to Anies as reference (coded 0). On the statistics see John Scott Long, Regression Models for Categorical and Limited Dependent Variables, 1st edition (Thousand Oaks: SAGE Publications, Inc, 1997); J. Scott Long and Jeremy Freese, Regression Models for Categorical Dependent Variables Using Stata (Texas: Stata Press, 2005). The results are not fully displayed because of limited space. They are available from the authors. Results are "difference in predicted probabilities," meaning how large 
Relative to other independent variables, resistance against nonMuslim leadership is on average the strongest predictor of voting for the governor (pooled data analysis). It decreased the likelihood of voting for Ahok very significantly $(\not<.001)$. The difference in probability was 55 points (Table 2). The second strongest predictor is also related to religion, being a Muslim instead of a non-Muslim (Table 2). The difference in probability was 47 . The effect is statistically very significant $(p<.001)$. Another religion-related predictor, support for prosecuting Ahok for violating the blasphemy law, also significantly decreased the likelihood of voting for him by .29 points. The difference in probability to vote for the incumbent over his opponent is also statistically very significant $(p<.001)$ (Table 2).

The three related religious identity variables are together responsible for the failure of Ahok and the victory of Anies. Other social identity variables, self-identification with a group and opinion about ethnic minority leadership, did not explain significantly the outcome (Table 2). This finding is consistent with there being no single majority ethnic group. Javanese at 36\% is the largest, but neither Anies nor Ahok is Javanese. Instead, they belong to small minorities, Sino-Indonesian for Ahok, Arab-Indonesian for Anies. This also explains why ethnic identity and opinion about minority leadership did not predict the election outcome. Religious identity and its mobilization, visible in the public opinion about resistance against leadership by a non-Muslim, plus the campaign against Ahok for blaspheming Islam, were far more significant. ${ }^{53}$

If religious identity had been the only factor responsible, however, Anies's victory margin would have been larger as Muslims (85\%) are much more numerous than non-Muslims (15\%). The fact that his

and statistically significant was the effect of each independent variable on making a differencc in voting for Ahok rather than Anies. For example, Muslim relative to nonMuslim decreased (negative) the likelihood to vote for Ahok relative to Baswedan. It makes a difference of , 47 points. The difference is statistically significant at $p<.001$.

53 Several months prior to the election, especially after the Kepulauan Seribu (Thousand Islands) incident where Ahok talked about Islam and the election, where he was claimed to have insulted Islam, mass mobilization against Ahok quickly became massive and brutal. Masses of protesters pressed the authorities to send him to jail. And they succeeded. "Demonstrasi 'Tolak Ahok' Berujung Bentrok", BBC News Indonesia (4 Nov 2016), https://www.bbc.com/indonesia/indonesia-37875413, accessed 31 Jul 2020. 
percentage was only $58 \%$ indicates that Muslims were not solidly behind him. Moreover, $42 \%$ voted for Ahok even though he belongs to a $15 \%$ religious minority. But his vote was larger than his religious minority status would suggest, indicating other factors at play. First, almost all nonMuslims voted for him. Second, political economy related variables, i.e. job approval of the incumbent and assessment of economic condition, probably added to his support. Personal qualities and partisanship likely played a role as well.

The incumbent's job approval was very high (mean of 3,62 on a 5 point scale), higher than the approval of the opinion against minority leadership (mean of 3,32 on a 5 point scale). This assessment helped increase the likelihood of voting for the incumbent by 4 . The effect is statistically very significant $(p<.001)$ (Table 2$)$. Another variable believed crucial is an assessment of economic condition. In the political economy or rational choice model, a positive assessment of economic condition will increase the probability to vote for the incumbent. If a voter's assessment of the economic condition is negative, it will increase the probability of voting for the opposition. As mentioned earlier, the public's assessment of the provincial economic condition was positive. Most voters stated that it was better now than last year. This positive assessment is believed to increase the incumbent's vote.

Multivariate analysis indicates that the political economy factor had a direct impact. Controlling for other variables such as incumbent's job approval, candidate personal qualities, party identification, religous identity, and some other variables, economic condition made a difference of ,24 point in increasing the probability of voting for the incumbent. The difference is statistically very significant $(p<.001)$ (Table 2$)$. A positive assessment of economic condition of Jakarta city, as theoretically expected, increases the likelihood to vote for the incumbent, Ahok.

Psychological factors are also believed to be crucial. They include the perception of personal qualities and partisanship. ${ }^{54}$ As described

54 Mujani, Liddle, and Ambardi, Voting Behavior in Indonesia since Democratization; King (ed.), Leaders' Personalities And The Outcomes Of Democratic Elections; Warren E. Miller and J. Merrill Shanks, The New American Voter (Cambridge, Mass: Harvard University Press, 1996); Bean and Mughan, "Leadership Effects in Parliamentary Elections in Australia and Britain"; Graetz and Mcallister, "Party Leaders and Election Outcomes in Britain, 1974-1983". 
earlier, Ahok was likable because of his competence, caring for people, and his integrity. This positive assessment increased the probability of voting for him very significantly $(p<.001)$. The difference in probability of a vote for Ahok relative to Anies was .33. Another psychological variable crucial to explain voting is partisanship. A party identifier will vote for a candidate nominated by that party. ${ }^{55}$ However, this variable as so defined is unlikely to work in this study because party identifiers in Indonesia have been so few. An alternative measure is voter intention. ${ }^{56}$

A significant number of political parties formed a coalition to nominate Ahok. They were PDI-Perjuangan, Partai Golkar, PPP (Unity Development Party), PKB (National Awakening Party), Nasdem (National Democrats), Hanura (People's Conscience), PKPI (Indonesian Justice and Unity Party), and PSI (Indonesian Solidarity Party). ${ }^{57}$ Gerindra, PKS, PAN (People's Message Party), and Perindo (United Indonesia Party) nominated Anies. ${ }^{58}$ If partisanship matters, voting for one of these parties will increase the voter's likelihood to vote for that party's candidate. If a voter voted for PDI-Perjuangan (Ahok's own party) for example, that voter is likely to vote for Ahok.

In addition, partisanship is believed crucial to suppress social

55 Campbell et al., The American Voter; Barnes et al., 'Party Identification and Party Closeness in Comparative Perspective'.

56 The number of voters who identify with a party in Indonesia is consistently small, about 10\%, too small to explain variation. See Mujani, Liddle, and Ambardi, Voting Behavior in Indonesia since Democratization. Our alternative measure is "voting for a party if an election is held now."

${ }^{57}$ This coalition constituted a majority in parliament after the 2014 parliamentary election and in the provincial legislature, also elected in 2014. In our analysis, voting for a party which supported Ahok is coded 3, for an independent or neutral party (Partai Demokrat, Democrat Party, and PBB, Moon and Star Party) or don't know is coded 2, and for a party which supported Anies is coded 1.

58 Of these coalitions, some Islamic or Islam-connected parties supported Anies, as one would expect on religious identity grounds, while the core of support for Ahok came from more secular parties. But this was not entirely the case, also to be expected in Indonesia as parties choose to support candidates for many reasons. For a discussion, see Mujani, Liddle, and Ambardi, Voting Behavior in Indonesia since Democratization. In addition, the term secular is contested in the Indonesian case. See Jeremy Menchik, "Moderate Muslims and Democratic Breakdown in Indonesia", Asian Studies Review, vol. 43, no. 3 (2019), pp. 415-33. 
identity by bridging the difference..$^{59}$ A Muslim, for example, will vote for a Christian if he or she and the candidate share the same party identification. In the case of the Jakarta gubernatorial election, a Muslim who voted for PDI-Perjuangan was expected to vote for Ahok if partisanship triumphed over religious identity. Partisanship did in fact matter (Table 2). In the last survey, exit poll, and pooled data, voting for a party allied to Ahok increased very significantly the likelihood of voting for Ahok. In the pooled data, partisanship made a difference in the probability of voting for Ahok relative to Anies by .4 points, statistically very significant $(\mathrm{p}<.001)$.

Table 2 Logistic Regression Analysis: Difference in Predicted Probabilities of Voting for Ahok (Relative to Anies)

\begin{tabular}{|c|c|c|c|c|c|c|c|}
\hline Variables & Ian 2017 & $\begin{array}{l}\text { Feb } \\
2017\end{array}$ & Mar 2017 & $\begin{array}{c}\text { Mar- } \\
\text { Apr } \\
2017\end{array}$ & Apr 2017 & $\begin{array}{c}\text { EP Apr } \\
2017\end{array}$ & Pooled \\
\hline Ahok blasphemed Islam & $-.31 * *$ & $-.27 * *$ & $-.26 *$ & $-.26 *$ & $-.38 * * *$ & $-.30 * * *$ & $-.29 * * *$ \\
\hline Muslim leader & $-.61 * * *$ & $-.48 * * *$ & $-.82 * * *$ & $-.60 * * *$ & $-.50 * * *$ & $-.44 * * *$ & $-.55^{* * *}$ \\
\hline Ethnic maiority leader & 0.00 & -0.09 & $0.35 *$ & -0.19 & -0.06 & -0.05 & -0.05 \\
\hline Incumbent performance & $0.64 * * *$ & $0.23^{* *}$ & $0.35 * *$ & $0.57 * * *$ & 0.09 & $0.62 * * *$ & $0.46^{* * *}$ \\
\hline Economic condition & $0.30 *$ & 0.16 & -0.12 & 0.21 & $0.23 *$ & $0.31 * * *$ & $0.24 * * *$ \\
\hline Personal dualities & $0.43 * * *$ & $0.23 * * *$ & $0.21 * *$ & $0.17 *$ & $0.23^{* * *}$ & $0.39 * * *$ & $0.34 * * *$ \\
\hline Partisanship & $0.33 * *$ & $0.29 * * *$ & 0.15 & $0.29 *$ & $0.37 * * *$ & $0.49 * * *$ & $0.40^{* * * *}$ \\
\hline Education & 0.04 & -0.05 & -0.16 & 0 & 0.07 & 0.13 & 0.01 \\
\hline Income & 0.19 & 0.13 & 0.12 & -0.18 & -0.08 & -0.01 & 0.04 \\
\hline Religion: Islam & -0.13 & $-.45 * * *$ & $-.60 * * *$ & $-.77 * * *$ & $-.76^{* * *}$ & $-.49 * * *$ & $-.47 * * *$ \\
\hline Ethnicitv: Iavanese & -0.03 & 0.08 & 0.15 & 0.19 & -0.03 & 0.05 & 0.05 \\
\hline Age & 0.19 & -0.18 & -0.23 & 0.04 & -0.15 & $0.24 *$ & 0.02 \\
\hline Gender (Male) & 0.06 & -0.04 & 0.07 & 0 & 0.03 & -0.02 & 0.01 \\
\hline $\mathrm{N}$ & 583 & 809 & & 414 & 720 & 1714 & 4623 \\
\hline
\end{tabular}

${ }^{* * *} \mathrm{p}<.001,{ }^{* *} \mathrm{p}<.01,{ }^{*} \mathrm{p}<.05$

Because of the positive effect of economic condition, job approval, likability, and partisanship, Ahok gained a larger number of votes than his

59 For example, the African-American Barack Obama, representing a minority, won the presidency twice because the party identification of most African-Americans and many other Americans is Democratic. 
religious identity would suggest. He won $42 \%$, larger than the Protestant $(7,5 \%)$ or total non-Muslim population (15\%). Anies won about $58 \%$, much smaller than the Muslim population (85\%). The political economy and psychological variables thus decreased his support. Overall, however, religious identity and its mobilization triumphed over the political economy and psychological factors, making Anies the winner. The nonreligious factors only preserved Ahok from a bigger loss.

\section{E. Concluding Remarks}

Scientific debates on the relative impact of social identity versus rational calculation and psychological factors have been inconclusive due to the lack of empirical data. In the case of Indonesian electoral politics, contestation occurs mostly among similar players. A minority person usually avoids competing against a member of the majority. In presidential elections, all contestants have been Muslim. At the local level, such as in gubernatorial elections, the pattern has been similar. There will be a candidate for governor from a minority group if there are more than one candidate from the majority group so that the majority power is divided into several groups whose strength is relatively the same as that of the minority group. The division of the majority group opens the opportunity for a candidate from the minority group to win a simple plurality vote in the election. However, this opportunity occurs very rarely. ${ }^{60}$

Because of this social identity-based calculation, a minority person usually avoids participation in contentious politics. The difference in social identity has therefore almost never been tested. The existing literature on Indonesian politics is not concerned with this issue because there have been few if any cases. Since almost everybody is Muslim, students of Indonesian politics, including electoral politics, have been more concerned with religious variation in Islam or types of Muslims. Scholars have been more concerned with orthodox versus heterodox

${ }^{60}$ In West Kalimantan, a Catholic won the governorship twice. Catholics, Protestants, and other non-Muslims constitute a significant percentage of the population, but Muslims are the majority. The Catholic won because Muslims were divided. Once Muslims nominated a single candidate they won. A similar pattern occurred in Central Kalimantan, where a non-Muslim won a gubernatorial election as Muslims were divided. They won subsequently when they had only one candidate against a non-Muslim candidate. 
Muslims, or with santri versus abangan.

The 2017 Jakarta gubernatorial election has provided an opportunity to test the resilience of identity politics. How realistic is the claim that Indonesian Muslims are politically pluralist and tolerant? Systematic analysis verifies that identity politics in this election was very strong. Religious identity and its mobilization determined how people voted. Most Muslims voted for a Muslim candidate, Anies, and almost all non-Muslims voted for a Christian candidate, Ahok. Because religious identity had a very strong impact, the Christian Ahok failed despite his positive performance in office. Non-identity politics — the incumbent's performance, personal qualities, and partisanship—only saved him from a bigger loss.

These findings suggest that in electoral politics, especially when social identities have been mobilized, that identity is likely to prevail over rational calculation. In contentious politics, the rational calculation works better when the identity division is neutralized. Religion defined in terms of Muslim religious variation, as in the classic Geertzian formulation, is too imprecise to make a claim that religion does not matter in Indonesian politics, that Indonesian voters are rational, and that Indonesian Muslims are pluralist and tolerant. Religion should be understood in a more primordial and fundamental way, as a deep historical division in many human civilizations. These divisions may have a tremendous impact if they are openly contested in a democracy.

Party identification and rational calculation are not strong enough to bridge social divisions and cleavages when political contestation is defined by social identity. In Indonesian electoral politics, the expectation that pluralism and tolerance will prevail is probably too high. Indonesian democracy has worked as well as it has so far in part because political tolerance and pluralism have not been strongly challenged by social identity-based candidates. Voters are rational, pluralist, and tolerant if social identity considerations are constant. When they are not, Indonesian democracy is not mature enough for more pluralist and tolerant voting behavior. Other democracies are probably not immune to these challenges as well. 


\section{Appendix 1}

Measures, wordings, and codings

Dependent variable:

Voting for governor: For which pair of governor-vice governor candidates would you vote were the gubernatorial election held now? 1. Basuki Tjahaya Purnama-Djarod Saiful Hidayat 2. Anies Baswedan Sandiaga Uno.

In the exit poll, the question was: For which pair of governor-vice governor candidates did you just vote? 1. Basuki Tjahaya Purnama-Djarod Saiful Hidayat 2. Anies Baswedan - Sandiaga Uno.

Coding: Voting for Basuki Tjahaja Purnama - Djarod Saiful Hidayat $=$ Ahok (1), and Anies Baswedan - Sandiaga Uno = Anies (0, reference).

Independent variables:

\section{Abok blasphemed Islam}

Do you agree that it is just to bring legal charges against Ahok for blaspheming Islam? 1 = disagree, 2 = don't know, 3 = agree.

\section{Muslim leader}

Some say Muslims are not allowed to be led by a non-Muslim. To what extent do you agree or disagree? 1 = strongly disagree, 2 = disagree, $3=$ don't know, $4=$ agree, or $5=$ strongly agree.

\section{Ethnic majority leader}

Some say a person from a minority ethnic group should not be allowed to lead a majority group. To what extent do you agree or disagree? $1=$ strongly disagree, $2=$ disagree, $3=$ don't know, $4=$ agree, or $5=$ strongly agree.

\section{Incumbent performance}

How satisfied or dissatified are you with the performance of Basuki Tjahaya Purnama as governor so far? 1 = very dissatisfied, 2 = dissatisfied, $3=$ don't know, $4=$ satisfied, or $5=$ very satisfied. 


\section{Economic condition}

How do you assess the current economic condition of Jakarta compared to last year? $5=$ much better, $4=$ better, $3=$ about the same, $2=$ worse, $1=$ much worse.

\section{Partisan choice}

For which party would you vote if an election for legislators was held now? Show a list of parties.

\section{Personal qualities}

Do you like Basuki Tjahaya Purnama? 3 = yes, $2=$ don't know, $1=$ no.

\section{Religion}

To which religion do you belong? Are you Muslim, Protestant, Catholic, Hindu, Buddhist, Confucian? If you belong to any other religion not on the list please state. Islam is coded 1 , others are coded 0 (reference).

\section{Ethnicity}

People commonly belong to an ethnic group such as Javanese, Sundanese, Betawi, Batak, Balinese, etc. To what ethnic group do you belong? Show list of ethnic groups. Javanese is coded 1, others are coded 0 (reference).

\section{Education level}

What is your most recent education level? Show the list of education levels. Please tell me which one fits yours. Please tell me if none apply. 1. Never went to school... 8. University graduate.

\section{Montbly income}

What is your monthly gross income? Show the list of incomes. Please tell me which one fits yours? Please tell me if none apply. 1. 200,000 rupiah or less.... 10. More than ten million rupiah.

\section{Age}

When were you born? Age was coded 17 or older. 


\section{Appendix 2}

Method, Data, and Statistics

This study is based on a series of public opinion surveys conducted by Saiful Mujani Research and Consulting (SMRC), an Indonesian public opinion research company (https://saifulmujani.com/). The surveys were conducted prior to election day, the exit poll on election day. The population is all Jakarta voters, citizens who were of voting age (17 or older), or who had already married before they were 17 . The sample size varies from 450 to 1800 .

For the pre-election surveys, respondents were selected at random. In order to draw representative samples, a multistage random sampling technique was applied. First, the population was stratified according to sub-districts (kecamatan) and gender proportion. There are 44 subdistricts. The respondents sampled in the surveys were selected at random and proportionally from lists of registered voters in each subdistrict. Selected voters, male and female, who agreed to be respondents, were interviewed. The lowest response rate from the surveys was $79 \%$, the highest $87 \%$.

The sampling procedure for the exit poll was different. First, the population was stratified according to subdistrict and gender proportion. In each district voters were grouped according to where they voted (TPS, Tempat Pemiliban Suara, Place of Voting). The number of TPS's varied for each subdistrict. To get a representative sample, as many as 500 TPS's were chosen randomly and proportionally according to subdistrict populations.

In each selected TPS, 4 respondents, 2 male and 2 female, were chosen according to 15 minute intervals as voters left the TPS from 7 AM, when it opened, until noon (12 PM), when it closed. Four 15 minute intervals between the opening and closing hours were chosen at random. Voters who left the TPS at the designated intervals are the ones who were chosen to be polled. Each polled voter's permission was requested before he or she was interviewed.

Interviews were conducted by trained interviewers, mostly university students. Quality was controlled by supervisors. About $50 \%$ of the respondents were selected at random to make sure the interviews were conducted properly.

The STATA program was used for the data analysis. Logistic 
regression was based on Long. ${ }^{61}$ The calculation of the difference in predicted probability is based on Long and Freese ${ }^{62}$ and Jann. ${ }^{63}$

${ }^{61}$ Long, Regression Models for Categorical and Limited Dependent Variables.

62 David C. Leege and Lyman A. Kellstedt, Rediscovering the Religious Factor in American Politics (Armonk, N.Y: Routledge, 1993).

63 Ben Jann, "Making Regression Tables Simplified", The Stata Journal, vol. 7, no. 2 (2007), pp. 227-44. 


\section{BIBLIOGRAPHY}

Andryanto, Dian, "Ahok Dihukum Dua Tahun, Putusan Hakim Bulat", Tempo, 9 May 2017, https:/ / nasional.tempo.co/read/873676/ahokdihukum-dua-tahun-putusan-hakim-bulat, accessed 30 Jul 2020.

Aspinall, Edward and Marcus Mietzner, "Indonesia's Democratic

Paradox: Competitive Elections amidst Rising Illiberalism", Bulletin of Indonesian Economic Studies, vol. 55, no. 3, 2019, pp. 295-317 [https:// doi.org/10.1080/00074918.2019.1690412].

Barnes, Samuel H. et al., "Party Identification and Party Closeness in Comparative Perspective", Political Behavior, vol. 10, no. 3, 1988, pp. 215-31 [https://doi.org/10.1007/BF00990552].

Bean, Clive and Anthony Mughan, "Leadership Effects in Parliamentary Elections in Australia and Britain", The American Political Science Review, vol. 83, no. 4, 1989, pp. 1165-79 [https://doi.org/10.2307/1961663].

BPS Provinsi DKI Jakarta, Hasil Sensus Penduduk 2010 Data Agregat per Kabupaten Kota Provinsi DKI Jakarta, Jakarta: BPS Provinsi DKI Jakarta, 2010.

Brug, Wouter van der, Cees van der EijK, and Mark Franklin, The Economy and the Vote: Economic Conditions and Elections in Fifteen Countries, 1st edition, Cambridge University Press, 2007.

Campbell, Angus et al., The American Voter, Chicago Ill.: University of Chicago Press, 1980.

Chandra, Kanchan, "What Is Ethnic Identity and Does It Matter?", Annual Review of Political Science, vol. 9, no. 1, 2006, pp. 397-424 [https://doi.org/10.1146/annurev.polisci.9.062404.170715].

Cochrane, Joe, "Jakarta Governor Concedes Defeat in Religiously Tinged Election”, The New York Times, 19 Apr 2017, https:/ /www. nytimes.com/2017/04/19/world/asia/jakarta-election-ahok-aniesbaswedan-indonesia.html, accessed 30 Jul 2020.

Dahl, Robert, The Future of Democratic Theory, Estudios / Working Papers, no. 90, La Rioja: Centro de Estudios Avanzados en Ciencias Sociales, 1996.

“Demonstrasi ‘Tolak Ahok' Berujung Bentrok”, BBC News Indonesia, 4 
Nov 2016, https://www.bbc.com/indonesia/indonesia-37875413, accessed 31 Jul 2020.

Fauzia, Mutia, "Ini 15 Orang Terkaya di Indonesia Tahun 2020 Halaman all", Kompas.com, 9 Apr 2020, https://money.kompas.com/ $\mathrm{read} / 2020 / 04 / 09 / 124003226 /$ ini-15-orang-terkaya-di-indonesiatahun-2020, accessed 30 Jul 2020.

Fiorina, Morris P., Retrospective Voting in American National Elections, Yale: Yale University Press, 1981.

Gaffar, Afan, Javanese Voters: A Case Study of Election Under a Hegemonic Party System, Yogyakarta: Gadjah Mada University Press, 1992.

Geertz, Clifford, The Religion of Java, Glencoe, Illinois: Free Press, 1960. Graetz, Brian and Ian Mcallister, "Party Leaders and Election Outcomes in Britain, 1974-1983", Comparative Political Studies, vol. 19, no. 4, 1987, pp. 484-507 [https://doi.org/10.1177/0010414087019004002].

Hale, Henry E., "Explaining Ethnicity", Comparative Political Studies, vol.37, no. 4, 2004, pp. 458-85 [https://doi.org/10.1177/0010414003262906]. Hasyim, Syafiq, "MUI and its discursive relevance for 'Aksi Bela Islam': A Growing Trend of Islamic Conservatism in Indonesia", in Rising Islamic Conservatism in Indonesia, ed. by Leonard C. Sebastian, Syafiq Hasyim, and Alexander R. Arifianto, Routledge, 2020, pp. 116-32. Horowitz, Donald L., Ethnic Groups in Conflict, Updated Edition With a New Preface, 2nd edition, Berkeley, Calif.: University of California Press, 2000.

Humas PKS Jakarta, "Surat Terbuka Wasekjen PKS ke Ahok Soal Katakata Kasar di Televisi", DPTW PKS DKI Jakarta, 20 Mar 2015, http:/ / pks-jakarta.or.id/surat-terbuka-wasekjen-pks-ke-ahok-soalkata-kata-kasar-di-televisi/, accessed 31 Jul 2020.

"Indonesia Should Become Reference for Studying Moderate Islam", News en.tempo.co, https://en.tempo.co/read/1277030/indonesiashould-become-reference-for-studying-moderate-islam-vp, accessed 29 Jul 2020.

"Jakarta Election: Christian Governor Concedes to Muslim Rival", BBC News, 19 Apr 2017, https://www.bbc.com/news/worldasia-39636974, accessed 30 Jul 2020. 
Jann, Ben, "Making Regression Tables Simplified", The Stata Journal, vol. 7, no. 2, 2007, pp. 227-44 [https://doi. org/10.1177/1536867X0700700207].

Kalin, Michael and Nicholas Sambanis, "How to Think About Social Identity", Annual Review of Political Science, vol. 21, no. 1, 2018, pp. 239-57 [https://doi.org/10.1146/annurev-polisci-042016-024408].

"Kapolri: Bukan Membela, Ahok Tidak Bermaksud Menistakan Agama", liputan6.com, 5 Nov 2016, https://www.liputan6.com/news/ $\mathrm{read} / 2644597 /$ kapolri-bukan-membela-ahok-tidak-bermaksudmenistakan-agama, accessed 31 Jul 2020.

Kiewiet, Roderick, Macroeconomics and Micropolitics: The Electoral Effects of Economic Issues, Chicago, Ill.: Univ of Chicago Pr, 1984.

King, Anthony (ed.), Leaders' Personalities and the Outcomes of Democratic Elections, 1st edition, Oxford: Oxford University Press, U.S.A., 2002.

Lamb, Kate, "Jakarta governor likely to be spared jail if found guilty of insulting Islam", the Guardian, 20 Apr 2017, http:/ /www.theguardian. com/world/2017/apr/20/ousted-jakarta-governor-basuki-tjahajapurnama-jail-blasphemy-indonesia, accessed 30 Jul 2020.

Leege, David C. and Lyman A. Kellstedt, Rediscovering the Religious Factor in American Politics, Armonk, N.Y: Routledge, 1993.

Lewis-Beck, Michael S., Economics and Elections: The Major Western Democracies, Ann Arbor: University of Michigan Press, 1990.

Liddle, R. William, Ethnicity, Party, and National Integration;: An Indonesian Case Study, New Haven: Yale University Press, 1970.

Liddle, R. William and Saiful Mujani, "Leadership, Party, and Religion: Explaining Voting Behavior in Indonesia", Comparative Political Studies, vol. 40, no. 7, 2007, pp. 832-57 [https://doi. org/10.1177/0010414006292113].

Lijphart, Arend, "Religious vs. Linguistic vs. Class Voting: The 'Crucial Experiment' of Comparing Belgium, Canada, South Africa, and Switzerland", The American Political Science Review, vol. 73, no. 2, 1979, pp. 442-58 [https://doi.org/10.2307/1954890].

Long, J. Scott and Jeremy Freese, Regression Models for Categorical Dependent Variables Using Stata, Texas: Stata Press, 2005. 
Long, John Scott, Regression Models for Categorical and Limited Dependent Variables, 1st edition, Thousand Oaks: SAGE Publications, Inc, 1997.

Mardiastuti, Rina Atriana, Aditya, "Hakim: Ahok Merendahkan Surat Al-Maidah 51", detiknews, 9 May 2017, https://news.detik.com/ berita/d-3496149/hakim-ahok-merendahkan-surat-al-maidah-51, accessed 30 Jul 2020.

Menchik, Jeremy, "Moderate Muslims and Democratic Breakdown in Indonesia", Asian Studies Review, vol. 43, no. 3, 2019, pp. 415-33 [https://doi.org/10.1080/10357823.2019.1627286].

Menchik, Jeremy and Katrina Trost, “A ‘Tolerant’ Indonesia? Indonesian Muslims in Comparative Perspective", in Routledge Handbook of Contemporary Indonesia, London: Routledge, 2018, pp. 390-405.

Mietzner, Marcus, "Fighting Illiberalism with Illiberalism: Islamist Populism and Democratic Deconsolidation in Indonesia", Pacific Affairs, vol. 91, no. 2, 2018, pp. 261-82 [https://doi. org/10.5509/2018912261].

----, "Rival Populisms and the Democratic Crisis in Indonesia: Chauvinists, Islamists and Technocrats", Australian Journal of International Affairs, vol. 74, no. 4, Routledge, 2020, pp. 420-38 [https://doi. org/10.1080/10357718.2020.1725426].

Mietzner, Marcus and Burhanuddin Muhtadi, "Explaining the 2016 Islamist Mobilisation in Indonesia: Religious Intolerance, Militant Groups and the Politics of Accommodation", Asian Studies Review, vol. 42, no. 3, 2018, pp. 479-97 [https://doi. org/10.1080/10357823.2018.1473335].

Miichi, Ken, "The Role of Religion and Ethnicity in Jakarta's 2012 Gubernatorial Election", Journal of Current Southeast Asian Affairs, vol. 33, no. 1, 2014, pp. 55-83 [https://doi. org/10.1177/186810341403300104].

Miller, Warren E. and J. Merrill Shanks, The New American Voter, Cambridge, Mass: Harvard University Press, 1996.

Mudzakkir, Tindak Pidana Terbadap Agama Dalam Kitab Undang Undang Pidana (KUHP) dan Undang Undang Nomor 1/PNPS/1995 Tentang Pencegahan Penyalahgunaan dan/atau Penodaan Agama: (Kajian Terbadap 
Praktek Penegakan Hukum dan Prospek Pengaturannya Dalam Hukum Positif Indonesia), Jakarta: Kementerian Hukum dan Hak Asasi Manusia, 2010.

Mujani, Saiful, Muslim Demokrat: Islam, Budaya Demokrasi dan Partisipasi Politik di Indonesia Pasca Orde Baru, Jakarta: Penerbit Gramedia Pustaka Utama cooperation with Pusat Pengkajian Islam dan Masyarakat, Yayasan Wakaf Paramadina, Freedom Institute, and Kedutaan Besar Denmark, 2007.

----, Agama dan Rasionalitas Pemilih: Kasus Pemilihan Gubernur DKI Jakarta 2017, Jakarta: Saiful Mujani Research and Consulting, 2017.

Mujani, Saiful, R. William Liddle, and Kuskridho Ambardi, Voting Behavior in Indonesia since Democratization: Critical Democrats, Cambridge: Cambridge University Press, 2018.

Niemi, Richard G. and Herbert F. Weisberg (eds.), Classics in Voting Behavior, Washington, D.C: CQ Press, 1992.

Novia, Dyah Ratna Meta, "PKS Sebut Kebijakan Ahok Berpihak pada Kelompok Pemilik Modal”, Republika Online, 17 Apr 2016, https:// republika.co.id/berita/nasional/jabodetabek-nasional/16/04/17/ o5r3iu336-pks-sebut-kebijakan-ahok-berpihak-pada-kelompokpemilik-modal, accessed 30 Jul 2020.

Penduduk Indonesia: Hasil Sensus Penduduk 2010, Jakarta: BPS-Statistic Indonesia, 2012.

"Penduduk Menurut Wilayah dan Agama yang Dianut: Provinsi DKI Jakarta", BPS-Sensus Penduduk 2010, http://sp2010.bps.go.id/ index.php $/$ site $/$ tabel?wid $=3100000000 \&$ tid $=321 \&$ fi1 $=58 \&$ fi $2=3$, accessed 31 Jul 2020.

Peterson, Daniel, Islam, Blasphemy, and Human Rights in Indonesia: The Trial of Ahok, 1st edition, London: Routledge, 2020.

"Pilkada Provinsi DKI Jakarta (Putaran Kedua)", KPU-Portal Publikasi Pemilihan Kepala Daerah 2017, https://pilkada2017.kpu.go.id/ hasil/2/t1/dki_jakarta, accessed 30 Jul 2020.

"PKS: Ahok Harus Tegas, tetapi Jangan Kasar", Kompas.com, 20 Jul 2015, https://money.kompas.com/read/2015/07/20/15215531/PKS. Ahok.Harus.Tegas.tetapi.Jangan.Kasar, accessed 30 Jul 2020. 
Purwanto, Heru, "KPU Tetapkan Fauzi Bowo-Prianto Pemenang Pilkada DKI 2007”, Antara News, 16 Aug 2007, https://www.antaranews. com/berita/74054/kpu-tetapkan-fauzi-bowo-prianto-pemenangpilkada-dki-2007, accessed 29 Jul 2020.

Santiarto, Dwiarso Budi, "Ini Kisah Perjalanan Kasus Ahok Hingga Vonis 2 Tahun Penjara", Tribunnews.com, 16 Nov 2016, https:/ /www. tribunnews.com/metropolitan/2017/05/09/ini-kisah-perjalanankasus-ahok-hingga-vonis-2-tahun-penjara?page $=3$, accessed $30 \mathrm{Jul}$ 2020 .

Suwarta, Thomas Harming, "Indonesia Menjadi Kiblat Toleransi di Dunia", Media Indonesia, 2 Jul 2017, https://mediaindonesia.com/ politik-dan-hukum/111128/indonesia-menjadi-kiblat-toleransi-didunia, accessed 29 Jul 2020.

The Constitution of the Republic of Indonesia of 1945, http:// www.unesco.org/education / edurights / media / docs / b1ba8608010ce0c48966911957392ea8cda405d8.pdf. 
Saiful Mujani 